\title{
Effectiveness of Secondary School Guidance Programs in Preparing Learners for Successful Transition to University: A Case of Moi University
}

\author{
R. Njage and L. Athiemoolam
}

\section{ABSTRACT}

The study aimed to establish the effect of secondary school guidance programs in preparing students for successful transition to university. Mixed methods research design was used which included the use of both quantitative and qualitative methods to generate data using a concurrent triangulation approach. Purposive sampling was applied to sample first year students in Moi University and proportionate sampling together with simple random sampling was used in the selection of 375 participants comprising both male and female students. Data were collected through questionnaires and focus group discussions. Quantitative data were analyzed using descriptive (mean and standard deviation) and inferential statistics by means of SPSS (Pearson Correlation Coefficient), followed by linear regression to test the hypothesis. Thematic analysis was used for qualitative data analysis. The findings of this study revealed that high school guidance programs do not support learners adequately in preparing them to transition to university. The study recommended the implementation of more enhanced collaboration between schools and universities for successful transition.

Keywords: first year university students, higher education, school guidance programs, student adaptation, university dropout rates, university transition.

Published Online: July 05, 2021

ISSN: $2736-4534$

DOI : $10.24018 /$ ejedu.2021.2.3.84

\section{R. Njage}

Moi University, Eldoret, Kenya.

(e-mail: njagerose ${ }^{@}$ gmail.com)

L. Athiemoolam*

Nelson Mandela University, Port Elizabeth, South Africa.

(e-mail: Logamurthie.athiemoolam@ mandela.ac.za)

*Corresponding Author

\section{INTRODUCTION}

University students could be confronted by a variety of challenges if proper guidance and support is not forthcoming, both from the schools where they matriculated and their universities; to support their transition from one institution to another. Transition refers to the behavioral and inner mental process that occurs when people experience adjustments and move from the known to the unknown, reacting to culture, social and reasoning challenges [13]. During their transition they may either accept or reject the changes in their lives. As much as it can take place rapidly, the transition process can pose numerous challenges. In this case, universities are taken to have multiple transitions in terms of culture, content (what is being taught), the environment and inter and intra-personal relationships. Due to this therefore, transition is assumed as an ongoing process in an individual's life, hence it is unavoidable.

First year students admitted to universities may be regarded as victors, since they performed so well in their final exam in secondary school [17]. Social transition into the University is a very important component for any student to become successful and for producing graduates with the requisite skills for socio-economic development [20]. Due to this therefore, transition of students to university is an important aspect that should be examined, because despite the expansion of secondary schools and institutions of higher learning in sub- Saharan Africa the throughput rate is still very low especially in terms of the skills and competencies among the graduates. This can only be achieved if there is a successful transition to university which, in this case, is the "factory" for producing successful citizens [6;31].

Coping with university life is not easy for any student, especially in terms of independent decision making, making new friends and academic involvement. If effective measures are not implemented, the student is likely to experience poor transition which will result in various challenges such as alcohol and drug abuse, rioting and irresponsible sexual behavior, or poor academic performance, delays in the completion of studies, incorrect course selection and misuse of finance and time. Due to this therefore, it is imperative for a student to have a successful transition in every stage of his or her life since it forms the basis for future success especially in career development. There has been growing academic concern of late that students are not well prepared for university studies especially in terms of course selection, hence leading to declining education standards [30].

Kalimasi and Chisalala [18] argue that in Africa, many secondary school leavers face challenges in university and in their career choices, because of poor guidance and inadequate information and skills from parents, peers, secondary school teachers and university personnel. Due to this therefore, career guidance and counselling by stakeholders in support of students is imperative to ensure successful transition to 
university and even to the professional world. According to [24], if the expectations of first year students' conflict with their experiences in University, they may become disorientated and hence may not succeed during other phases of their lives. According to [19,9,22] higher education is frequently the key ingredient in moving the needle away from unemployment and poverty towards employment and economic development. During the first year the student may feel confused, insecure, anxious, disturbed and even helpless especially during the first semester [7]. The same research contends that, as much as the number of students transiting from secondary school to university is high, it is important to retain the students up to completion. Successful transition to university is a very important stage for any individual admitted to the institution, since it forms the foundation for mature life, for making personal decisions and choice of careers, hence being a very important stage in one's life $[33 ; 15 ; 18]$. Many students excel in secondary schools in Kenya and therefore expect to be admitted to universities. The question is how well are these students prepared for university education? Even after the establishment of guidance and counselling programs in secondary schools and universities, students are still involved in criminal activities such as stealing, examination malpractices, irresponsible sexual behavior, rioting, alcohol and drug abuse and mismanagement of time leading to poor performance, drop outs and transfers from one faculty to another [26]. Hence the need to establish the effect of high school guidance programs on students' preparedness for transition to university.

\section{PURPOSE OF THE STUDY}

Moi University in Kenya is one of the largest and second oldest public universities in Kenya which has both an urban and rural setup, unlike others with either only urban or rural setting. These students could be experiencing different challenges according to the setup, hence affecting their transition to university. The low throughout rate among Moi university students, an increase in criminal activity among students, and the poor professional and coping skills among undergraduates led us to conduct this empirical investigation. The research question that guided this study was: How do first year university students in Kenya perceive the effectiveness of school guidance programmes in preparing them to transition from schools to university.

\section{THEORETICAL FRAMEWORK}

The study was based on two theories namely Havighurst's Developmental Task Theory [16] and Erikson's developmental theory [14]. The study used the theories because they complement each other. Havighurst's developmental task theory outlines the life stages and their respective characteristics while Erikson's developmental theory focuses on the crisis associated with each stage of human life that one has to overcome for a successful transition. Erikson classified human life into six stages, but the current study only focused on adolescence (13 to 18 years) and early adulthood (19 to 29 years) because first year students fall predominantly into these two stages. Havighurst [16] contends that every stage is characterized by some tasks that the individual must achieve for a successful transition to the next stage, and if these tasks are not achieved, the individual faces challenges transiting to the next level.

From Havighurst's discussion, the developmental tasks of early adulthood are selecting a partner of the opposite sex. The individual also achieves masculine or feminine social roles in society for instance girls acquiring the qualities of being good mothers and home makers and learning to live with a marriage partner. Furthermore, one learns how to detach from the parents and to be independent in life, especially in making decisions such as starting a family and rearing child. Moreover, during early adulthood, the individual starts to choose careers of his/her choice; hence this is a very important stage in the mature stage of life. The individual also takes responsibility for civic roles in society by behaving according to the societal expectations and finding congenial social groups to identify with away from family members. According to this study, first year students fall in the two stages, because most of them are separated from their families for the first time. Many students find themselves in universities far away from their localities, because selection is administered from a central office unlike private universities where admission is administered by the individual universities, although currently few government sponsored students are being admitted to these universities. In addition, some students, and especially high school friends, have branched off into different fields hence leading to students feeling lonely and isolated. It is also a stage where first year students form relationships away from family members, especially with the opposite sex, and make individual decisions on careers that they are not versed in.

Erikson's [14] developmental theory on the other hand divides human life into eight psychosocial stages and the current study applied adolescence (12-18) and young adulthood (19-40) as stages for the purposes of this study.

Every stage is accompanied by different crises that are formed due to a conflict emerging between the individual and societal needs, that are overcome by successful completion of the stage, hence personality development. Personality development of an individual enables one to achieve virtues and to transit to the next stage successfully. According to [14] the individual tries to be independent in decision-making to fit into society. It is after successful completion of this stage that an individual starts to form relationships with people outside their family, especially with the opposite sex, and also identifies with certain careers and if the individual does not transit successfully to this stage, isolation develops. In relation to the current study, first year students will become frustrated and discouraged if they do not proceed through a successful transition to university life, hence leading to poor academic performance, completely dropping out of university or even indulging in criminal activities. The two theories assisted the researchers in understanding the participants' experiences from a psychological perspective.

\section{LITERATURE REVIEW}

University students possess different levels of preparedness for transition by the time they are in their first year of study. These are in terms of individual life on campus and how to cope with university challenges. Another form of preparedness relates to career progression whereby every 
student should be made aware of various programs and prospective career advancement after university, as well as professional bodies in different professions. Before students join the university, some high school teachers offer them guidance concerning what to do and what not to do in regard to mode of dress, how to use their leisure time, the friends to keep, what food to eat and so on [33]. All the students need backing from their guardians, teachers, and fellow peers for successful transition. This can be motivational, financial, social, and informational [35]. A study conducted in Australia among Melbourne secondary school students found that a majority of secondary school teachers, especially career teachers, know very little about the courses being offered in universities, hence they mislead the students when it comes to career choice [2]. The former study was conducted among secondary school learners while this study was conducted among first year university students at Moi University who were experiencing the transition. The support provided to students at secondary school level in relation to their transition to university is vital if a student hopes to achieve a successful transition. For example, the strategies used to prepare students for transition from secondary school to university will influence their expectations of the university [10]. The mode of teaching, study habits and assessment in secondary schools will have a bearing on students' preparation for university contexts. A study conducted on university students' transition at Mzuni University in Malawi found that there was a major challenge in the selection of courses in the university. The level of preparedness for students was measured in terms of guidance and counselling, where it was reported that there was no career counselling both in secondary school and university on how students could select courses according to their capability [35]. This was evident by more than half of the students indicating that they were not aware of the careers available from the courses selected and the demands of the courses selected, hence attributing that to inadequate career guidance from secondary schools. Secondary schools in Malawi were reported to concentrate on students excelling in the final exam to join university, but there was no room to advise the students on the expectations of university education. The same study reported that $5 \%$ of the students joining university in Malawi dropped out before the end of the first semester, while more than half were found to drop out in the first and second year. The students interviewed attributed the high dropout rate to inadequate preparation in the courses that they selected. The result was that they ended up being confronted with many challenges, hence opting to drop out of the course or from the university. The Kenyan system of secondary education is not any different from what was reported in Malawi, therefore there is a need for research on the effectiveness of high school guidance programs in preparing students for successful transition to university. The support provided to students at secondary school level in relation to their transition to university is vital if a student hopes to achieve a successful transition. For example, the approaches used to prepare students for transition from secondary school to university will influence their expectations of the university [10]. The mode of teaching, study habits and assessment in secondary schools will have a bearing on students' preparation for university contexts. Cook [10], in his study, conducted among
American university students, found that a majority of the students were used to teachers spoon feeding them and mainly concentrating on independent study as opposed to group discussions, which are very common in universities. From the above discussion, Kenyan secondary schools tend to focus more on academic performance rather than on empowering students with skills to adapt to universities and the world of work. A study conducted in China on the experiences of first year students in universities found that many students felt that they were not adequately prepared for university transition [29]. Among their contentions were that they were being trained to work individually, not in a group, and that all the work they did was for the exams. According to these students the assessment in secondary school was about achieving a good grade to attend university and did not focus on individual growth. From the above discussion, students in Kenya are not an exception, since all secondary school teachers work hard to ensure that many students join university, hence forgetting other cycles of growth and development. While the Chinese study [29] only focused on the intellectual challenges faced by first year students during transition from secondary schools to universities, this study focused on academic and social levels of preparedness. In support of secondary school guidance, a study conducted in Tanzania on students' preparedness from post- secondary to higher learning and the world of work found that a majority of secondary school leavers were not fully informed about universities and career choices as well. There was a gap between the expectations of the university and the knowledge first year students were found to possess in terms of their courses and prospective careers [18]; some students, especially from towns, were found to possess at least some information about the university and what was expected of them. It was therefore evident that different students possessed different levels of preparedness as they joined university; some had adequate information and the relevant skills to apply in their university life, while others were not completely aware of the demands of university life. In general, a majority of first-year students lack the expected academic skills required by lecturers because of inadequate academic experience from high schools where they were taught by different instructors who used varied methods of teaching [8]. Most students know very little about university in terms of academic and social life by the time they join, leading to many challenges.

\section{ReSEARCh Methodology}

The paradigm that underpinned this study was pragmatism, whose aim was to determine practical solutions to problems and actual meanings of the results, using what works best and using it to understand the research problem [28]. This paradigm is of importance in this study on two levels; firstly it allowed the researcher to blend characteristics of quantitative and qualitative methods and secondly to identify concrete solutions to transitional issues in the university by sharing the findings and the recommendations [25]. According to [28] this paradigm allows for transferability and generalizability of the results which enabled the researcher to test for validity and reliability of data generated to enhance credibility. A mixed methods research design and concurrent triangulation strategy were used. This is a one phase design 
in which the researcher implemented both qualitative and quantitative methods for generating data at the same timeframe and with equal weight applied to them. The process involves concurrent, but separate, collection and analysis of data and the integration of results during presentation and interpretation time, for the researcher to understand the research problem best [12;4]. This design was employed because it enabled the researcher to validate data obtained from one method with another hence complementing the weaknesses of one method with the other's strengths.

\section{A. Sampling and Sample Size}

The target population for the purpose of this study were all first-year students from all the schools in the University under investigation, with a population of 4,651 , comprising both male and female students. The study was only conducted among first year students, because it is the group experiencing immediate transition from secondary school to university, which is a new environment. The study applied both probability and non-probability sampling techniques. For non-probability sampling, purposive sampling was applied to select first year students while for probability sampling, proportionate sampling was used to calculate the number of first year students to be selected from every school according to the total enrolment. Consequently, simple random sampling was applied to select the total sample size comprising equal numbers of male and female students. The study worked with a sample size of 375 at confidence level of $95 \%$ and margin of error of 5\% which was drawn from both male and female first year students in the schools within the university under study. After all the participants filled out questionnaires, the researcher randomly selected 50 participants from the same sample size, comprising 25 male and 25 female first year students to participate in focus group discussions. Five Focus Group Discussions (FGD) comprising 10 participants ( 5 male $\&$ female students) were formed. Table I below provides an outline of the sample size selection.

\begin{tabular}{cccc}
\multicolumn{4}{c}{ TABLE I: SAMPLE SizE SELECTION } \\
\hline Schools & Total Population & $(\%)$ & Sample Size \\
\hline A & 1409 & 2.28 & 106 \\
B & 455 & 0.74 & 34 \\
C & 720 & 1.17 & 54 \\
D & 15 & 0.02 & 1 \\
E & 1320 & 2.14 & 99 \\
F & 185 & 0.3 & 13 \\
G & 455 & 0.74 & 34 \\
H & 76 & 0.12 & 5 \\
I & 80 & 0.13 & 6 \\
J & 93 & 0.15 & 6 \\
K & 38 & 0.06 & 2 \\
L & 200 & 0.32 & 15 \\
Total & 4651 & 8.17 & 375 \\
\hline
\end{tabular}

Source: University Admissions.

\section{B. Data Collection}

The study applied both qualitative and quantitative approaches. For the qualitative section, focus group discussions were applied among 50 first year students from all the schools to generate data on the effectiveness of orientation received in preparing them for successful transition to university. The students were randomly sub- divided into 5 groups made up of 10 participants comprising equal numbers of male and female first year students. For the questionnaire, structured questions were administered among 375 first year students to generate data on their level of preparedness for transition offered through orientation programs received at the university. A five- point likert scale was used to measure academic, financial, time management and social skills using different questions for different constructs. Questionnaires were administered among 375 respondents, but data were successfully collected from 289 respondents giving a response rate of $77.06 \%$.

\section{FINDINGS}

Data on the effectiveness of high school guidance programs in preparing students for successful university transition were collected using items that were linked to the importance of this kind of support to any first year student and generated through questions that were framed in line with the importance of the program. Level of preparedness and high school guidance had a positive significant relationship $(\mathrm{r}=.670, \mathrm{p}<0.01)$ and regression results indicated that high school guidance and career guidance had a positive significant effect on level of preparedness $(\beta=.362, \mathrm{p}<0.05)$. As a result of this therefore, the null hypothesis that stated, "high school guidance programs have no statistically significant effect on students' preparedness for transition from secondary school to University" was rejected, and instead the alternative hypothesis was accepted that high school guidance programs have a statistical significant effect on students' preparedness for transition from secondary school to university.

\section{A. High School Guidance Program}

The overall mean for the items used to measure the effectiveness of high school guidance programs in enhancing first year students' successful transition to university was $2.6061(52 \%)$ which is above average. This percentage was contributed by only two items that scored a very high mean while the remaining three items scored very low means. Table II below shows descriptive statistics for the items used to measure the effectiveness of high school guidance programs in preparing students for successful transition to university.

TABLE II: DESCRIPTIVE STATISTICS FOR HIGH SCHOOL GUIDANCE

\begin{tabular}{|c|c|c|c|c|}
\hline & \multirow{2}{*}{ Code Item } & \multicolumn{2}{|c|}{ Mean } & \multirow{2}{*}{$\begin{array}{l}\text { SD } \\
\text { Stat }\end{array}$} \\
\hline & & Stat & $\mathrm{SE}$ & \\
\hline HSGP1 & $\begin{array}{l}\text { Effectively prepared me for transition to } \\
\text { university }\end{array}$ & 3.2111 & .08334 & 1.41682 \\
\hline HSGP2 & $\begin{array}{c}\text { Was adequate in preparing me for } \\
\text { university course }\end{array}$ & 1.7093 & .06555 & 1.11428 \\
\hline HSGP3 & $\begin{array}{l}\text { Prepared me on how to research } \\
\text { independently }\end{array}$ & 2.3702 & .06644 & 1.12944 \\
\hline HSGP4 & Prepared me for university & 3.0000 & .07546 & 1.28290 \\
\hline HSGP5 & $\begin{array}{l}\text { Prepared me on how to manage my } \\
\text { personal time }\end{array}$ & 3.0900 & .08670 & 1.47392 \\
\hline HSGP6 & $\begin{array}{l}\text { Prepared me to adjust to university } \\
\text { lecture method. }\end{array}$ & 2.2561 & .07213 & 1.22624 \\
\hline
\end{tabular}

Source: Survey data (2018).

\section{B. Preparedness for University Transition}

The item on high school guidance program providing support to high school students on transition to university scored a high mean of $3.21(62.2 \%)$. This means that there is 
an attempt by high school guidance and career teachers to prepare students for university transition, but not in all areas as seen from descriptive statistics and from focused group discussions. In terms of gender, $26.29 \%$ of male students felt that high school guidance programs prepared them for transition to university while $15.91 \%$ of the females were of a similar opinion. This means that more male students were prepared by high school guidance programs than their female counterparts. On the other hand, $19.03 \%$ of the respondents were not sure whether the high school guidance program contributed to their transition to university.

Most students indicated that they were able to balance their leisure and study time hence posting a high mean of 3.09 $(61.9 \%)$. Contrary to this, however, the findings from focus group discussions were different since the majority of students who participated in the discussion confessed that they experienced problems managing their time, since they had a lot of free time at university. Some of the respondents said the following, "There is just enough free time for yourself and the things you love to do but then there is excess." (FG1R9/L20-21/P.8) Another one said, "Majority of the first-year student normally they have a lot of wasting time." (FG3R8/L29/P.12).

Other students claimed that they were not able to manage their time at the university because in high school there were bells and teachers that guided them on what to do. "We had bells in high school, we had teachers telling us what to do, we had morning prep, and then I'm here being told that I'm support to be in class by eight a.m., and there is no morning prep, there is no bell. I can't make it." (FG1R1/L23-25P.17)

This disagrees with a study conducted in Tunisia among first year English students at the Institute of Languages, whose results found that the students were able to manage their time properly and were also eager to learn [3].

\section{Course Selection}

In terms of course selection, $52.94 \%$ of the male students responded that high school guidance programs did not prepare them for university course selection while $26.64 \%$ of their female counterparts were of a similar opinion. Only $9.34 \%$ of the male and $6.22 \%$ of the female respondents admitted that high school guidance helped them for university course selection. This finding is depicted by the low mean of the item 1.71(34.2\%) compared to other items used to measure the effectiveness of high school guidance program. These findings were not different from focus group discussions where some of the students said the following, "Personally, I was not informed because I thought the course am going to pursue was maths oriented, and then here comes the case the first two lectures is history and I personally I hated history since back in high school." (FG3R2/L2224/P.3). Another respondent said, "when I was applying for my courses was not well informed about the courses you know for the high school student you have passed well so you feel you are the giant now you go online and find courses with big names the names sound sweet so you say I can fit there let me try. " (FG5R5/L6-9P.7)

Other students confessed that they were very confused with the courses that they attended at the university due to a lack of proper guidance from secondary school. This is what they reported, "For me I didn't know even the course I was to select. Even I didn't know about clusters. In fact, I was reading the course I was just reading the name. I even ended up choosing a course that had low cluster points." (FG2R9/L11-14/P.2) Another respondent said, "Aahh... I was called to be a musician, but I ended up in law... (all laughed)...I was not informed at all about my course selection, I started researching about law when I bonded a mat from Nairobi to Eldoret, easy coach to report." (FG1R7/L3-5/P.10)

The above findings concur with that of [18], who conducted a study in Tanzania on students' preparedness from post- secondary to higher education and the world of work. The study found that most secondary school leavers were not provided with adequate information relating to universities and career choices as well. This was also not different from the report of a study conducted at the University of Ulster on the preparedness of first-year students for transition to University [10]. The study indicated that 17 $\%$ of the first-year students were not aware of course selection in the first year and only $14 \%$ were acquainted with the choices that could be made. In the same study, $18 \%$ were found to be completely oblivious to how these choices were assessed and $26 \%$ were not aware of whether the courses involved selection. Similarly, in a study conducted in the USA, the findings showed that of the 2.2 million first year students, between 25 and $30 \%$ change their courses when they reach the second semester of their first and the first semester of their second year [28]. One of the respondents stated that in their secondary school, teachers were guiding them on courses according to their preference without considering the students' needs, while others were not conversant with the current courses that universities offered, hence misguiding the students.

"Some teachers were giving us courses which were not offered on campus." (FG3R3/L14pg1) "Some teachers wanted us to do some specific courses which they saw best for us which were not inclined with what we wanted to do." (FG3R3/L15-16/P.1)

The findings of this study concur with a study conducted in Australia among Melbourne secondary schools students, that found that the majority of secondary school teachers, especially career teachers and parents, know very little about the courses being offered in the Universities hence they mislead the students when it comes to career choice [2;23].

Contrary to the above discussion, some respondents reported that guidance programs in their respective secondary schools were effective in preparing them for university transition especially in career development. One of the students reported that they had job shadows in their secondary school, during which they would be taken to different fields for experience before selecting university courses. "In $m y$ high school we actually went for job shadows so that you are able to be acquainted with what you wanted to do." (FG1R5/L13-14/P.2) This is a good strategy that can even be adopted by the Ministry of Education. Students who were exposed to job shadowing were more confident about their courses and could explain what their courses entailed, and the specific careers aligned to them. 


\section{Research Skills Preparedness}

The item on individual research preparedness scored a low mean of $2.37(47.4 \%$ ) with $68.51 \%$ of respondents admitting that the high school guidance programs did not equip them with research skills hence they experienced challenges when required to conduct individual research. Only $21.79 \%$ of the respondents reported to have acquired research skills from high school guidance programs while $8.9 \%$ were found to be confused as to whether they possessed any research skills. Other respondents in the focus groups confessed that most of them did not do assignments but instead, waited for a few of their peers to complete them and copied. "A few students do assignment, but the rest could take from them, so a few do for the others. But majority do copy paste only a few attempts." (FG3R8/L4-5/P.15) This explains the reason as to why; despite the expansion of secondary schools and institutions of higher learning in sub Saharan Africa, the throughput rate is still very low especially in terms of the skills and competences among the graduates.

\section{E. Lecture Method of Teaching}

$60.89 \%$ of students acknowledged that high school guidance did not prepare them for adjustment to the university lecture method; $21.79 \%$ were prepared for the university lecture method, while $17.30 \%$ of the students indicated that they had not decided whether they were prepared for this teaching method. From focus group discussions, some students indicated that guidance and counselling in secondary school was not effective in preparing them for university transition, since most of the issues discussed related to life in secondary school, with limited reference to focusing on university life. In some secondary schools, some respondents reported that they did not have a Department of Guidance and Career Development; hence they were not prepared for university transition. "They handle high school issues, they tell you do not do drugs and study a lot, but they do not prepare you for future."(FG1R2/L20-21/P.1) and that, "It's a failing department in as much as or when you consider preparedness levels in transition to university." (FG1R2/L 22-23/P.1).

In as much as the Department of Counselling in school was not effective in preparing the students for transition, some of the students also confessed that they had negative attitudes towards counselling, hence they did not attend the sessions, while others slept during the counselling sessions. From this therefore, students' attitudes matter a lot in terms of their preparation for the transition to any stage in life, or even in education. "In high school when most talks are about to happen, that is the time people are planning to go sleep during the talk coz that is what used to happen like you find people carrying jackets and sweaters when the whole time people are talking they haven't focused on that coz they term it as a boring thing." (FG1R3/L32-35/P.1).

The findings relating to the preparation given through secondary school guidance programs on transition to university indicates that there is a gap between the two stages. A majority of the secondary school guidance programs seem to have concentrated on secondary school issues at the expense of preparing students to successfully transit to university. Some of the teachers were reported to have limited information pertaining to different courses offered at the university, while others forced students to select courses that were of interest to them, without emphasizing the needs of the learners first. On the same finding, a majority of first year students expressed a lack of knowledge relating to cluster points hence facing challenges during university course selection.

Level of preparedness and high school guidance had a positive significant relationship ( $\mathrm{r}=.670, \mathrm{p}<0.01)$. Regression results indicated that high school guidance programs had a positive significant effect on level of preparedness $(\beta=.362, p<0.05)$. This led to the rejection of the hypothesis $\left(\mathrm{H}_{0}\right)$ that stated that high school guidance program has no statistically significant effect on students' preparedness for transition from secondary school to university. This implies that the high school guidance program is a vital area in ensuring students' successful transition to university, but currently the program is not providing the best support to students.

\section{DISCUSSION}

The findings of the study indicate that there is a preparation gap for high school students who are aspiring to join university. This is in terms of courses available and their requirements, time management, social life, and financial management. $52.94 \%$ of male students responded that high school guidance programs did not prepare them for university course selection while $26.64 \%$ of their female counterparts were of a similar opinion. Only $9.34 \%$ of the male and $6.22 \%$ of the female respondents admitted that high school guidance helped them for university course selection. A few students reported that they were adequately prepared for university education and life by the guidance program in high schools. This implies that there could be confusion among first year students especially in terms of what course to pursue, hence resulting in wasting time as they transit between faculties to decide on the programme of study they would like to pursue.

It emerged that although career guidance was offered in secondary schools, most students were still not prepared for course selection. Many reported that they were confused in terms of what course to select, since they did not have knowledge of the content and selection of courses. By the time they selected courses, some did not know about the different cluster points required by different courses.

The study found that most secondary school leavers were not provided with adequate information relating to universities and career choices as well. This means that there is a mismatch between students' expectations and what is offered at university. This may result in a mismatch between the skills acquired by the students and the requirements in the job market. This was also not different from the report of a study conducted at the University of Ulster on the preparedness of first year students for transition to University [14]. The study indicated that $17 \%$ of the first-year students were not aware of course selection in the first year and only $14 \%$ were acquainted with the choices that could be made. In the same study, $18 \%$ were found to be completely oblivious to how these choices were assessed and $26 \%$ were not aware of whether the courses involved selection.

High school teachers were found to be lacking in their knowledge on university course selection, since they advised students to apply for courses and programs of study that are 
no longer offered by the university. Could it be that the teachers responsible for career guidance in high schools are also not versed in these requirements? The findings emerging from this study concur with a study conducted in Australia among Melbourne secondary schools students, that found that the majority of secondary school teachers, especially career teachers and parents, know very little about the courses being offered in the universities hence they mislead the students when it comes to career choice $[2 ; 23]$.

In terms of applying Havighurst's [16] and Erikson's [14] frameworks to the overall findings of the study it appears as if the majority of first year students are stuck and are unable to transit successfully from secondary school to university. Most of them seem to have stagnated at the adolescent stage level and face challenges of transiting to the early adulthood stage. As a result, they develop some crisis due to frustration such as poor performance leading to drop-out, changing from one course to another and antisocial behaviour. Furthermore, they are not able to make suitable career choices, make decisions on their own, behave according to societal norms at that stage and are also not able to identify with new groups of people away from the family. On the other hand, first year students that were well supported by high school guidance programs were found to have a successful transition to university and managed to start their early adult life without any crisis.

\section{CONCLUSION}

The findings emerging from this study, indicate that the level of students' preparedness for transition from secondary school to university depends on support given through high school guidance programs. Furthermore, if teachers, who are involved in facilitating such programs at secondary school level, make concerted efforts to work collaboratively with coordinators of first year university orientation programs, more meaningful outcomes will ensue. This will ultimately lead to better prepared students who will be able to transition more smoothly from secondary to university contexts. However, there is a need to examine the effectiveness of school-university partnerships to facilitate the transition from secondary schools to universities in future research studies. There should be collaborative programs by secondary schools and universities in making high school students aware of university courses and university life in general. Preparation for university education should start from the first form, and not form four. This could contribute to a more informed selection of university courses, hence enabling students to settle down more effectively without having to switch from one course to another.

\section{REFERENCES}

[1] Abdullah, M. C., Elias, H., Mahyuddin, R., \& Uli, J. 2009. Adjustment amongst first year students in a Malaysian university. European Journal of Social Sciences, 8 (3): 496-505.

[2] Abramson, D., Lowe, G., \& Atkinson, P. 2000. Are you interested in computers and electronics? (pp. 1-5). Paper presented at the proceedings of the Australasian conference on computing education, ACM 2000.

[3] Amri, Z. 2014. High school transition to university: a bridge to gap. European Journal of Research on Education, Special Issue: Contemporary Studies: 54-58.
[4] Ayiro, L. P. 2012. A functional approach to educational research methods and statistics: qualitative, quantitative, and mixed methods approaches. Lewiston, N.Y: Edwin Mellen Press.

[5] Biesta, G. 2010. Pragmatism and the philosophical foundations of mixed methods research. Sage handbook of mixed methods in social and behavioral research, pp. 95-118. Melbourne: Sage publications. at https://dx.doi.org/10.4135/9781506335193. Accessed on 20th July 2018.

[6] Bloom, D. E., Canning, D., \& Chan, K. 2006. Higher education and economic development in Africa (Vol. 102). Washington, DC: World Bank.

[7] Brinkworth, R., McCann, B., Matthews, C., \& Nordström, K. 2009. First year expectations and experiences: Student and teacher perspectives. Higher Education, 58 (2): 157-173.

[8] Byrne, M., Flood, B., Byrne, M., \& Flood, B. 2015. A study of accounting students' motives, expectations and experiences 9486(September). Available at https://doi.org/10.1080/03098770500103176 (Accessed on 24th April 2018).

[9] Cloete, N., \& Maassen, P. 2015. Roles of universities and the African context. Knowledge Production and Contradictory Functions in African Higher Education, 1:1-17.

[10] Cook, A. 2014. Mind the gap: Are students prepared for higher education? Journal of Further and Higher Education, 27: 53-76.

[11] Creswell, J.W. 2003. Advanced mixed methods research designs. Handbook of mixed methods in social and behavioral research (209. 240). London: Sage Publications.

[12] Creswell, J. W., \& Creswell, J. D. 2017. Research design: Qualitative quantitative, and mixed methods approaches. New Delhi: Sage publications

[13] Edwards, D., Hawker, C., Carrier, J., \& Rees, C. 2015. A systematic review of the effectiveness of strategies and interventions to improve the transition from student to newly qualified nurse. International Journal of Nursing studies, 52 (7):1254-1268.

[14] Erikson, E. H. 1994. Identity: Youth and crisis. New York: WW Norton \& Company.

[15] Hanna, L.-A., Hall, M., Smyth, P., \& Daly, S. 2014. I miss being spoonfed: A comparison of transition from school to university education from the perspective of undergraduate pharmacy students. Pharmacy Education, 14 (7): 44-50.

[16] Havighurst, R. J.1972. Developmental tasks and education. New York: David McKay Company.

[17] Hodgson, P., Lam, P., \& Chow, C. 2011. Assessment experience of first-year university students: dealing with the unfamiliar (pp. 2-3). Paper presented at the enhancing learning experiences in higher education: International conference at University of Hong Kong, Hong Kong on $1^{\text {st }}$ of December 2011

[18] Kalimasi, P., \& Chisalala, N. 2016. Students' preparation from postsecondary to higher education and working life: information gap for successful transitions in Tanzania. Uongozi Journal of Management and Development Dynamics, 27 (1): 34- 84

[19] Kuy, K. 2015. Research paper deficiency in higher education in Cambodia: Poverty alleviation. Academic article on social issues. At http://khmerscholar.com/deficiency-in-higher-education-in-cambodiapoverty-alleviation/ Accessed on 26 November 2019.

[20] Labadi, S. 2017. UNESCO, world heritage, and sustainable dvelopment: International discourses and local impacts. In Gould, P. E., Pyburn, K. A. (Eds), Collision or collaboration (pp. 45-60). Basel, Switzerland: One World Archaeology, Springer International Publishing Switzerland.

[21] Lewin, T., \& Mawoyo, M. 2014. Student access and success: Issues and interventions in South African universities. Cape Town: InyatheloThe South African Institute for Advancement.

[22] Maree, J. 2009. Career counselling in the 21st century: South African institutions of higher education at the crossroads. South African Journal of Higher Education, 23(3): 436-458.

[23] McCarthy, M., \& Kuh, G. D. 2006. Are students ready for college? What student engagement data say. Phi Delta Kappa, 87 (9): 664-669.

[24] McInnis, C., Hartley, R., Polesel, J., \& Teese, R. 2000. Non-completion in vocational education and training and higher education. Melbourne: Centre for the Study of Higher Education.

[25] Morgan, D. L. 2007. Paradigms lost and pragmatism regained: Methodological implications of combining qualitative and quantitative methods. Journal of Mixed Methods Research, 1(1): 48-76.

[26] Nakalema, G., \& Ssenyonga, J. 2014. Academic stress: its causes and results at a Ugandan university. African Journal of Teacher Education, 3, 3 https://doi.org/10.21083/ajote.v3i3.2762 Accessed on 15 October 2019.

[27] Onwuegbuzie, A. J., \& Johnson, R. B. 2006. The validity issue in mixed research. Research in the Schools, 13 (1): 48-63. 
[28] Rausch, J. L., \& Hamilton, M. W. 2006. Goals and distractions: Explanations of early attrition from traditional university freshmen. The Qualitative Report, 11(2), 317-334. https://doi.org/10.46743/ 2160-3715/2006.1676

[29] Shannon-baker, P. 2016. Making paradigms meaningful in mixed methods research, Available at https://doi.org/10.1177/1558689815575861. Retrieved on 24th April 2018.

[30] Tang, Y. V., \& Wong, S. L. 2014. Bridging students: successful transition from high school to college. In unlocking borders in education: proceedings of the 3rd pre-university conference, 6 September 2014, Bandar Sunway. Proceeding of the Sunway academic conference 2014. Sunway College Kuala Lumpur, Bandar Sunway, pp. 38-43.

[31] Trotter, E., \& Roberts, C. A. 2006. Enhancing the early student experience. Higher Education Research \& Development, 25 (4): $371-$ 386.

[32] Vavrus, F., Thomas, M., \& Bartlett, L. 2011. Ensuring quality by attending to inquiry: Learner-centered pedagogy in sub-Saharan Africa. Addis Ababa, Éthiopia: UNESCO-IICBA.

[33] Venezia, A., Jaeger, L., Venezia, A., \& Jaeger, L. 2017. Transitions from high school to college. The Future of Children, 23 (1): 117-136.

[34] Wangeri, T., Kimani, E., \& Mutweleli, S. M. 2012.Transitional challenges facing university first year students in Kenyan public universities: a case of Kenyatta University. Interdisciplinary Review of Economics and Management, 2 (1): 41-50.

[35] Yakaboshi, T., \& Birnbaum, M. 2013.The challenge of student affairs in Kenyan public universities. Journal of Student Affairs in Africa, 1 (2): 33-48.

[36] Zozie, P. A., \& Kayira, P. B. 2012. Transition and tertiary education: a case study of Mzuzu University, Malawi. Research in Comparative and International Education, 7 (4): 434-445.

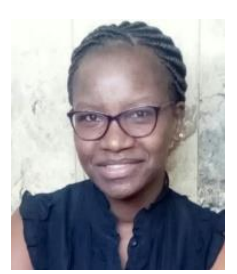

Rose Njage is an educationist born in 1988 in Chuka County- Kenya. She is Kenyan and DAAD Scholar who holds a Masters' degree in Education Research from Moi University, Kenya (2019). She is currently pursuing a second Masters' degree in Geography at Kenyatta University, Kenya. She is a First-Class holder in undergraduate studies in Education Arts from Moi University, Kenya (2013). She is an enthusiastic educationist with extensive experience in teaching and mentoring students from various cultural and social backgrounds through effective teaching methods that stimulate learning environments.

She is a HIGH SCHOOL TEACHER with Teachers Service Commission (TSC) teaching Geography and Christian Religious Education (CRE) in Kiambu County. Throughout her career, she has maintained a track record of excellent performance. She is interested in educational research, integrated watershed management research and environmental management and conservation. Ms. Njage is a professional teacher registered with Teacher Service Commission of Kenya (TSC)

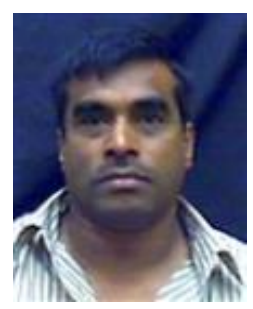

Logamurthie Athiemoolam was born in 1962 in East London, South Africa. He completed his B. Paed (Arts) majoring in English and Afrikaans through the University of Durban Westville (now UKZN) in 1985. In 1986 he studied towards an Honours degree in Education through Rhodes University in Grahamstown, which he completed in 1988. Thereafter, he completed his Masters' degree in Alternative Education through the then University of Port Elizabeth (now Nelson Mandela University) in 1994, and a Doctor in Education degree (D. Ed) through the University of Port Elizabeth (South Africa) and the Carl von Ossietzky University in Oldenburg (Germany). He first taught languages at a secondary school in Port Elizabeth before joining Vista University as a lecturer in Education and languages in 1997. In 2004 he joined the Nelson Mandela University where he has been lecturing, conducting research, supervising Masters, and Doctoral students in the fields of diversity pedagogy, language education and issues and challenges in education.

Professor Athiemoolam has been involved in various international partnerships including the CERMESA program that was a partnership between the University of Oldenburg (Germany), the Nelson Mandela University and East African Universities including Moi University in Kenya. He also completed a Summer Institute through the University of Indiana (USA) in 1999 in multicultural education. His awards include Teacher of the Year at the Nelson Mandela University in 2012 and researcher of the Faculty of Education (NMU) in 2019. He has written numerous articles and book chapters in the fields of drama pedagogy, multicultural education, language learning and teaching and literature. 